\title{
ERRATUM \\ Javaslat néhány agrokémiai alapfogalom pontosítására
}

\author{
BUZÁs István
}

Szent István Egyetem, Georgikon Kar, Talajtani és Környezetinformatikai Tanszék, Keszthely

\author{
Erratum: Agrokémia és Talajtan 69 (1-2) (2020) 91-105 \\ DOI: $10.1556 / 0088.2020 .00063$
}

A fenti cikkben a jelzett mondatokat hibásan, így a szerző közlési szándékával ellentétes jelentéssel közöltük:

\section{3. oldal. - Hibás szövegrész:}

"A trágyaszükséglet az a tápanyag/tápelem mennyiség, amelyet trágya formájában kell adni ahhoz, hogy az az adott talajon a növény tápelemigényét kielégítse, vagyis a tervezett mennyiségü és minőségű termény megteremjen."

\section{Helyesen:}

"A trágyaszükséglet az a tápanyag (tápelem) mennyiség, amelyet trágya formájában ki kell adnunk ahhoz, hogy a növény az adott talajon a tápelemigényét ki tudja elégiteni, vagyis megteremjen az általunk tervezett mennyiségü és minöségü termény."

\section{0. oldal. - Hibás szövegrész:}

"A talaj tápanyagvizsgálata során kapott eredmények akkor használhatók trágyaadag kiszámításához, ha kísérletileg megállapított a talajvizsgálati értékek, a trágyaadag és a legnagyobb/legjobb minőségü termés kapcsolata."

\section{Helyesen:}

"A talaj tápanyagvizsgálata során kapott eredmények akkor használhatók trágyaadag kiszámításához, ha kísérletekkel megállapitjuk, hogy az egyes talajvizsgálati értékeket mutató talajokon mekkora trágyaadaggal lehet a legnagyobb, és/vagy a legjobb minöségü termést elérni." 